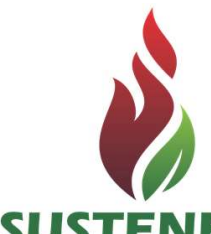

SUSTENERE

Publishing Corporation

\section{ASSESSMENT OF THE FIRST DECADE (1994-2004) OF WEST INDIAN MANATEE' REINTRODUCTION (TRICHECHUS MANATUS) PROGRAM IN THE NORTHEASTERN COAST OF BRAZIL}

\section{RESUMO}

Thirteen captive manatees were released and tagged in three different northeastern coastal areas as part of the Brazilian Manatee Reintroduction Program from October 1994 to December 2004. All individuals were monitored locally with VHF transmitters and four were also tracked with satellite tags for different lengths of time. Manatees were tracked from Praia do Forte, Bahia state $\left(12.538^{\circ} \mathrm{S} / 38.474^{\circ} \mathrm{W}\right)$ to Macau, Rio Grande do Norte state $\left(5.084^{\circ} \mathrm{S} / 36.682^{\circ} \mathrm{W}\right)$ along 1200 coastal $\mathrm{km}$ of the northeast six states. To evaluate the re-adaptation process was the main objectives of this work, which will hopefully help researchers to make decisions in the future. Two release areas (RA) were beaches with shallow waters, seagrass beds, reefs and close to small rivers; and one was located inside a large estuary with few seagrass beds. Captivity time was not considered in this evaluation but can be an important factor on the success of the manatee reintroduction program. Five manatees occupied home ranges and each contained sites of high fidelity where they spent considerable time. Two manatees were re-captured shortly after release, having moved long distances, including offshore movements into deep waters. Six manatees had few tracked time. Although manatees had few age when released they have found natural conditions for them survival including reproductive behavior. The fidelity sites choose to release manatees in terms of environmental was very similar. A discontinuous occurrence area (RA2) has been used by some released manatees where a first released manatee female had her calf. We strongly recommend: Continuous of this Manatee Reintroduction Program, to protect this three released areas, develop studies in fidelity sites and one new release area in Ceara coast.

PALAVRAS-CHAVE: West Indian Manatee; Reintroduction; Trichechus Manatus: Radio Telemetry; Peixe-boi.

\section{AVALIAÇÃO DA PRIMEIRA DÉCADA (1994-2004) DE OESTE REINTRODUÇÃO MANATEE' INDIANO (TRICHECHUS MANATUS) PROGRAMA NA COSTA NORDESTE DO BRASIL}

\section{ABSTRACT}

Treze peixes-boi em cativeiro foram liberados e marcou em três áreas costeiras do nordeste diferentes como parte do Programa Brasileiro Reintrodução do peixe-boi de outubro de 1994 a dezembro de 2004. Todos os indivíduos foram monitorados localmente com transmissores VHF e quatro também foram monitorados com etiquetas de satélite para diferentes comprimentos de tempo. Os peixes-boi foram rastreados a partir de Praia do Forte, Bahia $\left(12.538^{\circ} \mathrm{S} / 38.474^{\circ} \mathrm{W}\right)$ para Macau, Rio Grande do Norte $\left(5.084^{\circ} \mathrm{S} / 36.682^{\circ} \mathrm{W}\right)$ ao longo de $1200 \mathrm{~km}$ do litoral do nordeste seis estados. Para avaliar o processo de re-adaptação foram os principais objetivos deste trabalho, que esperamos ajudar os pesquisadores a tomar decisões no futuro. Duas áreas de soltura (RA) foram praias com águas rasas, ervas marinhas, recifes e perto de rios pequenos; e um foi localizado dentro de um grande estuário com poucos leitos de algas marinhas. Tempo de cativeiro não foi considerado nesta avaliação, mas pode ser um fato importante no sucesso do programa de reintrodução do peixe-boi. Cinco peixes-boi ocupada varia casa e cada um continha os locais de alta fidelidade, onde eles passaram um tempo considerável. Dois peixes-boi foram re-capturado logo após o lançamento, tendo se mudado para longas distâncias, incluindo os movimentos no mar em águas profundas. Seis peixes-boi teve pouco tempo registado. Embora peixes-boi tinha poucos anos, quando lançou eles encontraram condições naturais para a sobrevivência deles, incluindo o comportamento reprodutivo. Os sites de fidelidade optar por liberar peixes-boi em termos de meio ambiente era muito similar. A área de ocorrência descontínua (RA2) tem sido utilizada por alguns peixes-boi liberados em que um primeiro peixe-boi fêmea lançado tiveram sua panturrilha. Nós recomendamos fortemente: Contínuo deste programa de reintrodução do peixe-boi, para proteger este três áreas liberadas, desenvolver estudos em locais de fidelidade e uma nova área de lançamento no litoral do Ceará.

KEYWORDS: West Indian Manatee; Reintrodução; Manatus de Trichechus; Radio Telemetry; Peixe -boi.
Natural Resources, Aquidabã, v.5 n.1, Set, Out, Nov, Dez 2014, Jan, Fev, Mar, Abr, Mai, Jun, Jul, Ago 2015.

ISSN 2237-9290

SECTION: Articles

TOPIC: Megafauna aquática

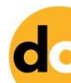

DOI: 10.6008/SPC2237-9290.2015.001.0003

Régis Pinto de Lima

Instituto Chico Mendes de Conservação da Biodiversidade, Brasil http://lattes.cnpq.br/5149180797409019 regis.lima@icmbio.gov.br

José Zanon Passavante Universidade Federal de Pernambuco, Brasil http://lattes.cnpq.br/7147339394595199 zanon@ufpe.br

Received: 30/09/2015

Approved: 30/09/2015

Reviewed anonymously in the process of blind peer.

\section{Referencing this:}

LIMA, R. P.; PASSAVANTE, J. Z.. Assessment of the first decade (1994-2004) of west indian manatee

reintroduction (trichechus manatus) program in the northeastern coast of Brazil. Natural Resources,

Aquidabã, v.5, n.1, p.29-44, 2015. DOl: http://dx.doi.org/10.6008/SPC22379290.2015 .001 .0003 


\section{INTRODUCTION}

Many calves of West Indian manatee (Trichechus manatus) have stranded in beaches of the Brazilian northeast (LIMA, 1999), being rescued and translocated to the Aquatic Mammals Center/ICMBio, in Itamaracá, Pernambuco $\left(7.802^{\circ} \mathrm{S} / 34.835^{\circ} \mathrm{W}\right)$, whose mission involves these calves' recovery for further reintroduction. From October 1994 to December 2004, thirteen animals recovered in captivity were released in three areas of reintroduction in the northeast coast, all young, where eleven were calves and two sub adults. All these animals were individually tagged by subcutaneous devices (transponders) and had their free life monitored by radio transmitters (DEUTSCH, 2003). The main objective was to oversee the process of re-adaptation and to understand how the manatees raised in captivity and reintroduced have used the natural environment. The monitoring covered the coast of six northeastern states, between Do Forte Beach/Bahia $\left(12.538^{\circ} \mathrm{S} / 38.474^{\circ} \mathrm{W}\right)$ and Macau/Rio Grande do Norte $\left(5.084^{\circ} \mathrm{S} / 36.682^{\circ} \mathrm{W}\right)$, within an extension of $1200 \mathrm{~km}$ of coastline. Five of these animals (39.5\%) had a period of monitoring over than 14 months (Total= 339; Maximum= 88.7; Mean=67.7; SD= 52.4) and they met the criteria for inclusion in the spatial and temporal analysis. From these five monitored animals and which take part of this study, three presented a moving behavior along the coast, characterizing an extensive Area of Life within that and used few areas of continuous permanence (Sites of Fidelity). Other two animals monitored in this study had an Area of Life restrict to an unique Site of Fidelity.

The other manatees even reintroduced received little time of monitoring and do not take part of this study, but contributed with information important for the Program. Two animals in little time of monitoring had to be recaptured due to presenting a continuous and erratic movement, being one rescued from 85 meters depth waters in the coastline of Sergipe. Four animals did not have sufficient time of monitoring. A standard of seasonal movements for those animals of extensive Area of Life was observed, where the dry season presented the larger occurrence of round trips to the Site of Fidelity. The present article intends to assess the Program of Reintroduction regarding two important factors of this process: the influence of the areas chosen for releasing and ecological indicators of the species. The survival and adaptation of five animals monitored for a long term, the resettlement in areas of discontinuity, as well as the birth of a calf in natural environment in 2003, can be described as indicators of the success of this pioneer Program of Reintroduction.

\section{METHODOLOGY}

The assessment of any program of reintroduction is vital to guarantee its continuity and whether the proposed objectives are being reached. The monitoring of the individuals in a short and long term (PRIMACK \& RODRIGUES, 2001), the analysis of the obtained results, as well as of the experiences acquired along the program execution are essential in this stage. The procedures and criteria for choosing which animals should be primarily reintroduced, their morphometric 
features, considering techniques of management and transport of big aquatic animals, of potential reintroduction areas, construction of captivity places and use of VHF transmitters by radio can be found in the Protocol of Reintroduction of Marine Manatees in Brazil. For this study, the data of the reintroduced monitored animals are shown in Table 1.

Table 1: Data of the three reintroduced manatees, with their respective sizes, period of captivity and places of strand and release. The numbers in parenthesis are codes of each animal in the data base of the Projeto Peixe-Boi Marinho.

\begin{tabular}{|c|c|c|c|c|c|c|c|c|c|c|}
\hline \multirow[t]{2}{*}{ Animal (ID) } & \multirow[t]{2}{*}{ Sex } & \multirow[t]{2}{*}{ Origin } & \multirow{2}{*}{$\begin{array}{l}\text { Length } \\
\text { when } \\
\text { Rescued } \\
(\mathrm{cm})\end{array}$} & \multirow{2}{*}{$\begin{array}{l}\text { Length } \\
\text { when } \\
\text { released } \\
(\mathrm{cm})\end{array}$} & \multicolumn{2}{|l|}{ Rescue } & \multicolumn{2}{|l|}{ Release } & \multirow[b]{2}{*}{$\begin{array}{l}\text { Period } \\
\text { in } \\
\text { Captivity } \\
\text { /Recove } \\
\text { ry (days) }\end{array}$} & \multirow[b]{2}{*}{$\begin{array}{l}\text { Period in } \\
\text { Captivity } \\
\text { / } \\
\text { Environ } \\
\text { ment } \\
\text { (days) }\end{array}$} \\
\hline & & & & & Date & Place & Date & Place & & \\
\hline $\begin{array}{l}\text { Astro } \\
(\mathrm{S} 0111 / 5)\end{array}$ & $M$ & FO & 133 & 238 & 24/04/1991 & Aracati(CE) & 21/12/1994 & Paripueria(AL) & 1320 & 70 \\
\hline $\begin{array}{l}\text { Lua } \\
\text { (S0112/4) }\end{array}$ & $\mathrm{F}$ & FO & 120 & 234 & $26 / 02 / 1991$ & Beberibe(CE) & 21/12/1994 & Paripueira(AL) & 1380 & 70 \\
\hline $\begin{array}{l}\text { Aldo } \\
\text { (S0111/15) }\end{array}$ & $M$ & FO & 114 & 163 & 23/02/1996 & Aracati(CE) & $25 / 09 / 1998$ & \begin{tabular}{|l} 
Porto de \\
Pedras $(A L)$
\end{tabular} & 930 & 0,7 \\
\hline $\begin{array}{l}\text { Pipa } \\
\text { (S0112/19) }\end{array}$ & $\mathrm{F}$ & FO & 130,5 & 204 & 05/11/1996 & $\begin{array}{l}\text { Tibau do } \\
\text { Sul(RN) }\end{array}$ & $25 / 09 / 1998$ & \begin{tabular}{|l} 
Porto de \\
Pedras $(A L)$
\end{tabular} & 680 & 0 \\
\hline $\begin{array}{l}\text { Xuxu } \\
\text { (S0111/9) }\end{array}$ & $M$ & FOI & 130 & 270 & $27 / 05 / 1989$ & $\begin{array}{l}\text { Ceará- } \\
\text { Mirim(RN) }\end{array}$ & 20/04/1999 & Rio Tinto(PB) & 3570 & 496 \\
\hline $\begin{array}{l}\text { Folia } \\
\text { (S0112/6) }\end{array}$ & $\mathrm{F}$ & $\mathrm{FO}$ & 135 & 284 & 05/03/1992 & Beberibe(CE) & 20/04/1999 & Rio Tinto(PB) & 2580 & 496 \\
\hline $\begin{array}{l}\text { Aparecida } \\
\text { (S0112/28) }\end{array}$ & $\mathrm{F}$ & $A D$ & 264 & 243 & $30 / 03 / 1998$ & Rio Tinto(PB) & 04/05/1999 & \begin{tabular}{|l} 
Porto de \\
Pedras $(A L)$
\end{tabular} & 390 & 0 \\
\hline $\begin{array}{l}\text { Araqueto } \\
\text { (S0111/23) }\end{array}$ & $M$ & FO & 118 & 222 & 06/02/1997 & Aracati(CE) & $10 / 08 / 2001$ & \begin{tabular}{|l} 
Porto de \\
Pedras $(A L)$
\end{tabular} & 1620 & 7 \\
\hline $\begin{array}{l}\text { Boi-Voador } \\
\text { (S0111/16) }\end{array}$ & $M$ & FO & 120 & 212 & 28/02/1996 & São Luis(MA) & $10 / 08 / 2001$ & \begin{tabular}{|l} 
Porto de \\
Pedras $(A L)$
\end{tabular} & 1980 & 7 \\
\hline $\begin{array}{l}\text { Assu } \\
\text { (S0111/94) }\end{array}$ & $M$ & FO & 140 & 223 & $23 / 02 / 2000$ & Aracati(CE) & $21 / 10 / 2003$ & \begin{tabular}{|l} 
Porto de \\
Pedras $(A L)$
\end{tabular} & 1320 & $07 / 07 / 14$ \\
\hline $\begin{array}{l}\text { Nina } \\
\text { (S0112/99) }\end{array}$ & $\mathrm{F}$ & FO & 137 & 212 & $08 / 01 / 2001$ & Cascavel(CE) & $21 / 10 / 2003$ & $\begin{array}{l}\text { Porto de } \\
\text { Pedras }(A L)\end{array}$ & 990 & 7 \\
\hline $\begin{array}{l}\text { TICO } \\
\text { (S0111/113) }\end{array}$ & $M$ & FO & 123 & 202 & $18 / 03 / 2001$ & \begin{tabular}{|l} 
Canto \\
Verde(CE)
\end{tabular} & $27 / 11 / 2004$ & $\begin{array}{l}\text { Porto de } \\
\text { Pedras }(A L)\end{array}$ & 1320 & 7 \\
\hline $\begin{array}{l}\text { Tuca } \\
\text { (S0112/116) }\end{array}$ & $F$ & FO & 125 & 217 & $30 / 11 / 2001$ & $\begin{array}{l}\text { Praia de } \\
\text { Pipa(RN) }\end{array}$ & $27 / 11 / 2004$ & $\begin{array}{l}\text { Porto de } \\
\text { Pedras }(A L)\end{array}$ & 1080 & 7 \\
\hline
\end{tabular}

Source: Changed, LIMA et al. (2007).

Legend: Length; $\mathrm{M}=$ Male; F = Female; FO = Orphaned Calf; FOI = Orphaned Calf from an Inadequate Captivity; AD = Weak Adult.

Some bio-ecological conditions for the species'survival and how these were presented (or absent) in the process of reintroduced manatees' adaptation process were qualitatively analyzed for assessing the Trichechus manatu's first reintroductions in the Brazilian coast. The influence of the areas of reintroduction in this process of the animals' adaptation was analyzed by comparing the present (or absent) ecological aspects in the areas of permanence, or sites of fidelity (SF) used by the reintroduced animals. The main ecological aspects of similarity compared were: beach protected by reefs, sea grass bed of Halodule wrightii and access to river/estuary (distance $<0.01$ or $1.1 \mathrm{~km})$.

\section{Influence of Areas of Reintroduction on Animals' Adaptation}

Can the Areas of Reintroduction (AR), that is, those previously chosen for hosting animals, remarkably influence on their choice of Sites of Fidelity (SF) when in free life? For those who define where the animals will have their first contact with natural environment after years in captivity, the answer was the relationship between the Area of Reintroduction and the Sites of 
Fidelity, that is, the relationship between the place they were released with the places they used along their free life. When the animals used the surroundings of their AR for a period after released which can classified as Site of Fidelity, it was considered that this AR accomplished its function of temporary area of adaptation, even if the animal had had other SF more significant in terms of permanence. If they permanently used the surroundings of their areas of reintroduction, that AR became a Site of Fidelity (SF), with total influence on those animals' post release life. When the reintroduced manatees immediately went far from their this place of release starts to not influence in their process of adaptation.

The Areas of Reintroduction were chosen from the map of current distribution of the species in the northeast coast of Brazil (LIMA, 1999). All the reintroductions were made during the dry season (Sep.-Mar), when the waters turbidity is lower and consequently the growth of aquatic vegetation is higher.

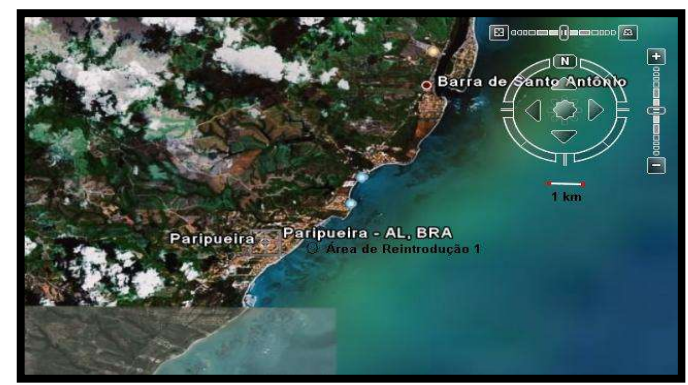

Figura 1: Aerial view of the Area of Reintroduction 1. Source: Google Earth.

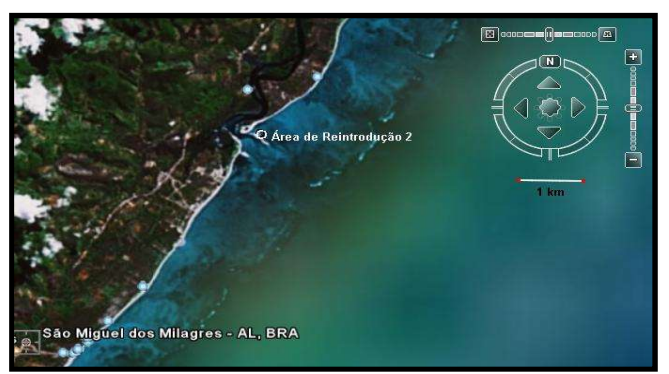

Figura 21: Aerial view of the Area of Reintroduction 2. Source: Google Earth.

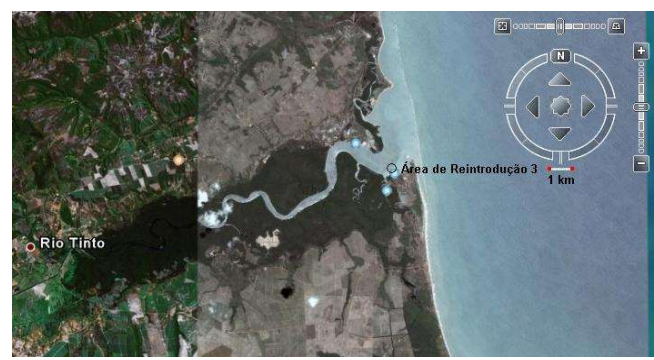

Figura 3: Aerial view of the Area of Reintroduction 3. Source: Google Earth.

Food and freshwater availability, intensive human occupancy, presence of other manatees, geographical area of animal's origin and if the place are marine protected area, besides the facilities for logistic support for the work during the period of captivity were the criteria assessed before choosing the place of release. 
Table 2: Areas of Reintroduction (AR) and their main ecological features.

\begin{tabular}{|l|l|l|l|l|}
\hline $\begin{array}{l}\text { Area of } \\
\text { Reintroduction }\end{array}$ & Natural Feeding & Source of freshwater & Mnvironment & Marine Protected Area \\
\hline $\begin{array}{l}\text { AR1. } \\
\text { Paripueira/AL } \\
\text { Lat 9.466 S } \\
\text { Long 35.536W }\end{array}$ & H. wrightii, algae & $\begin{array}{l}\text { Distant 3,4 km from Sauaçui } \\
\text { River and 5,5 km from Sapucaí } \\
\text { River }\end{array}$ & $\begin{array}{l}\text { Beach protected by reefs } \\
\text { ("inner sea") }\end{array}$ & $\begin{array}{l}\text { Federal Environment Protected } \\
\text { Area - APA Costa dos Corais }\end{array}$ \\
\hline $\begin{array}{l}\text { AR2. } \\
\text { Do Patacho/AL } \\
\text { Lat 9.222 S } \\
\text { Long 35.323 W }\end{array}$ & H. wrightii, algae & $\begin{array}{l}\text { Distant 5,8 km from } \\
\text { Tatuamunha and 3,5 km from } \\
\text { Manguaba River }\end{array}$ & $\begin{array}{l}\text { Beach protected by reefs } \\
\text { ("inner sea") }\end{array}$ & $\begin{array}{l}\text { Federal Environment Protected } \\
\text { Area - APA Costa dos Corais }\end{array}$ \\
\hline $\begin{array}{l}\text { AR3. } \\
\text { Barra de } \\
\text { Mamanguape/PB } \\
\text { Lat 6.766 S } \\
\text { Long 34.931 }\end{array}$ & $\begin{array}{l}\text { Mangrove, H. } \\
\text { wrightii (few), } \\
\text { algae }\end{array}$ & Mamanguape River & $\begin{array}{l}\text { Estuary with mangroves } \\
\text { and barrier reefs ("inner } \\
\text { sea") }\end{array}$ & $\begin{array}{l}\text { Federal Environment Protected } \\
\text { Area - APA Foz do Rio } \\
\text { Mamanguape }\end{array}$ \\
\hline
\end{tabular}

The two places of reintroduction in Alagoas (Figures 1 and 2) which were near mouth of rivers, presented a coast protected by sandstone reefs (GUERRA \& MANSO, 2004; LIMA, 1999), with natural food. In Paraíba, the place chosen was inside of the estuary of Mamanguape River (Figure 3), in a lateral channel. The higher tide amplitude in this coastal region is between 0.0 and 2.7m (Ministry of Navy/DHN, 2006).

\section{Success Indicators of the Reintroductions}

The post release assessments must consider each individual and several aspects (PRIMACK \& RODRIGUES, 2001). The opportunity the field team had to observe reintroduced animals allowed the records of the ecological condition related criteria. For LIMA et al. (2000), it was possible to record in field the environmental and behavioral criteria which served to indicate the success or not of the reintroductions, due to the ease to daily observe the reintroduced animals. Human interactions with these animals raised in captivity also could be observed. Besides these criteria, veterinarian interventions collected materials and data for analyzing the animals' health. In this only the criteria shown in Table 2 had their data systematically collected and were considered for assessing the success of reintroductions:

Table 3: Criteria to determine the success indicators of reintroductions

\begin{tabular}{|l|l|}
\hline CRITERIA & DEFINITION \\
\hline Food & Capacity of feeding in the natural environment \\
\hline Use of habitat & Permanence in an habitat appropriate to its ecology \\
\hline Human Interaction & Use of freshwater sources \\
\hline Reproduction & Low or gradate loss of affinity with humans \\
\hline
\end{tabular}

Source: LIMA et al. (2007).

The results to be analyzed from these criteria are going to be presented by a table of qualitative indicators (partial, total, unsuccessful, insufficient data) for five animals with sufficient monitoring time for this qualitative analysis. Similarity is here defined as those environmental/ecological conditions equally found in different areas. 


\section{RESULTS}

\section{Influence o the Areas of Reintroduction on Animals' Adaptation}

The qualitative analysis of the influence on an Area of Reintroduction (AR) seeks for elements to understand the importance of the chosen place in the process off re-adaptation of the manatees in natural environment and if this was incorporated a Site of Fidelity. The ranges of distance $(\mathrm{km})$ between the Sites of Fidelity (SF) established by each reintroduced manatee and its respective Area of Reintroduction (AR) were calculated. Yet, the main ecosystem characteristics of each AR (Table 1), present or absent in the SF were regarded, trying to identify the similarity of ecological niches between these two different places.

Table 4: Relation between LUA's, ASTRO's, ALDO's, XUXU's and NINA's Sites of Fidelity's distances and their Areas of Reintroduction's distances, where there is similarity in AR: 1= Beach protected by reefs. 2= banks of Halodule wrightii. $3=$ access to river (distance $\leq 0.01^{\circ}$ latitude or $1 \mathrm{~km}$ ).

\begin{tabular}{|c|c|c|c|}
\hline & SF1 & SF2 & SF3 \\
\hline $\begin{array}{l}\text { LUA } \\
\text { Distance AR1 }\end{array}$ & $45 \mathrm{~km}$ & $30 \mathrm{~km}$ & $1 \mathrm{~km}$ \\
\hline Similarity AR1 & $\begin{array}{l}1=\text { yes } \\
2=\text { yes } \\
3=\text { yes }\end{array}$ & $\begin{array}{l}1=\text { no } \\
2=\text { yes } \\
3=\text { yes }\end{array}$ & $\begin{array}{l}1=\text { yes } \\
2=\text { yes } \\
3=\text { yes }\end{array}$ \\
\hline $\begin{array}{l}\text { ASTRO } \\
\text { Distance AR1 }\end{array}$ & $\begin{array}{l}\text { SF1 } \\
240 \mathrm{~km}\end{array}$ & $\begin{array}{l}\text { SF2 } \\
30 \mathrm{~km}\end{array}$ & $\begin{array}{l}\text { SF3 } \\
1 \mathrm{~km}\end{array}$ \\
\hline Similarity AR1 & \begin{tabular}{|l|}
$1=$ no \\
$2=$ yes \\
$3=$ yes
\end{tabular} & $\begin{array}{l}1=\text { no } \\
2=\text { yes } \\
3=\text { yes }\end{array}$ & $\begin{array}{l}1=\text { yes } \\
2=\text { yes } \\
3=\text { yes }\end{array}$ \\
\hline $\begin{array}{l}\text { ALDO } \\
\text { Distance AR2 }\end{array}$ & $\begin{array}{l}\mathrm{SF} 1 \\
1 \mathrm{~km}\end{array}$ & SF2 & SF3 \\
\hline Similarity AR2 & \begin{tabular}{|l|}
$1=$ no \\
$2=$ yes \\
$3=$ yes
\end{tabular} & & \\
\hline $\begin{array}{l}\text { XUXU } \\
\text { Distance AR3 }\end{array}$ & $\begin{array}{l}\text { SF1 } \\
60 \mathrm{~km}\end{array}$ & $\begin{array}{l}\text { SF2 } \\
100 \mathrm{~km}\end{array}$ & $\begin{array}{l}\text { SF3 } \\
310 \mathrm{~km}\end{array}$ \\
\hline Similarity AR3 & $\begin{array}{l}1=\text { no } \\
2=\text { yes } \\
3=\text { yes }\end{array}$ & $\begin{array}{l}1=\text { no } \\
2=\text { yes } \\
3=\text { yes }\end{array}$ & $\begin{array}{l}1=\text { yes } \\
2=\text { yes } \\
3=\text { yes }\end{array}$ \\
\hline $\begin{array}{l}\text { NINA } \\
\text { Distance AR2 }\end{array}$ & $\begin{array}{l}\text { SF1 } \\
1 \mathrm{~km}\end{array}$ & SF2 & SF3 \\
\hline Similarity AR2 & $\begin{array}{l}1=\text { no } \\
2=\text { yes } \\
3=\text { yes }\end{array}$ & & \\
\hline
\end{tabular}

LUA's two main SF were the farthest from AR1, where it is situated its SF3, which obtained only $10.52 \%$ of the total localizations (LIMA, 2008). LUA only did not stay in a sandy beach protected by reefs when in the SF2, Mundaú Lagoon. Mundaú-Manguaba Lagoon is a semi-closed estuarine complex, with no tides, which has similarity as function of protected environment and of food and freshwater supply. ASTRO's two main SF were the farthest too, where the SF1 was more than $200 \mathrm{~km}$ to the to the south of its area of reintroduction. Its two main Sites of Fidelity (SF) environmentally characterized by interior waters, estuaries and coastal lagoons influenced by tide and which dispose available food. In the SF1, it is observed that besides the estuary of Vaza Barris River, the animal remarkably seeks Mangue Seco (SE/BA) as well as the estuary of Real River 
and Fundo River more to the south, during summers. Maré Mansa Beach (SF3), near the AR1, was the first SF after release was used only in the first years, as LUA's example.

Showing only one SF which also covered its Area of Life, ALDO little explored the northeastern coast, staying near the nursery in its first eighteen days (1998), where used the environment protected by reefs and sea grass bed of Halodule wrightii, before entering Tatuamunha River. It is observed that the beach environment where the nursery was has a great quantity of macrophytes (Halodule wrightii) and marine algae. In the interior of its Site of Fidelity, the most showy vegetation is the one which compounds the marginal mangrove, where there is some sea grass bed in bottom river. XUXU displaced much before define its SF's, where its closer distance between its SF and AR is sixty kilometers to the north. His two main Sites of Fidelity (SF) were environmentally characterized by estuaries with available food and environments forming an habitat protected by wave actions. In the SF1, it was observed that the animal stayed in the interior of the small Sibaúma River/RN, area sheltered by wave actions, daily displacing from the river mouth to out of the reefs, substrate where marina algae are predominant, feeding item for the marine manatee. In this region, the animal was seen several times beside other native manatees (ALVITE, personal communication). In this SF, the animal also displaced to the estuary of Cunhaú River/RN, always close to the reefs of range. There is a bar (Tonho's) in the interior of Sibaúma River where interaction with human was very intense. As Goiana River (SF2), which divides Paraíba and Pernambuco States, is a medium-sized river. Sea grass bed of Halodule wrightii are common in the margins and sandbanks of the estuary mouth. In the interior of the river, there are also aguapés and aningais. The barrier reefs are farther the estuary mouth. Adjacent to the estuary, more to the south, in Ponta de Pedras Beach, there are continuous sea grass bed of Halodule wrightii which goes until Itamaracá Island, with its two estuarine channels (Santa Cruz Channel). Maré Mansa Beach (SF3) was already described as SF for LUA and ASTRO.

With an only one SF measuring the same as its Area of Life, NINA little explored the northeastern coast, staying closer to the nursery in its first three days, ending up stranding. For $A L D O$, as mentioned, the protected beach environment where the nursery was in has a biomass of sea grass (Halodule wrightii) and marine algae much bigger the those of the Tatuamunha River.

\section{Success Indicators/Range of Reaching}

The post releasing assessments regarded each reintroduced manatee and the range of reaching of different behavioral and environmental aspects was considered to infer whether the animal presented a partial or total success in its free life rehabilitation. Data from blood and biometric tests were not analyzed. Since this was the first evaluation of marine manatees reintroduced in nature in Brazil, the in loco observations were the main sources which generate this study, which found this descriptive methodology and supply a comparative but still subjective 
assessment. For those five manatees with long monitoring period, there was a qualitative assessment: a) the main environmental conditions for a marine manatee survival in nature (food, habitat use, freshwater availability); continuing or no continuing interaction with human beings, once these animals spent their first life stage in captivity; c) observations of in loco reproductive behaviors.

Table 5: Environmental criteria of human and reproductive interactions assessed and related to five reintroduced manatees, where: Total= Criterion fully reached; Partial= Criterion partially reached; Unsuccessful = Criterion not reached; ID= insufficient data (need another form for inferring).

\begin{tabular}{|l|lcccc|}
\hline CRITERIA & SUCCESS & & & & \\
& LUA & ASTRO & ALDO & XUXU & NINA \\
\hline Food & Total & Total & Total & Total & Total \\
\hline Use of habitat & Total & Total & Total & Total & Total \\
\hline Freshwater & Total & Total & Total & Total & Total \\
\hline Human Interaction & Partial & Partial & Total & Partial & Partial \\
\hline Reproduction & Total & ID & ID & ID & ID \\
\hline
\end{tabular}

The success of female LUA's rehabilitation was demonstrated by its adaptation to free life and ability to explore coastal environments. It was also observed that this female had a healthy development, including a successful pregnancy. The main human interactions are due to the proximity with the places LUA preferred, with constant presence of people in the beaches, rivers and in Mundaú-Manguaba Lagoon, places whose demographic densities vary from few tens (SF1, SF3) to hundreds of thousands of people (SF2). This behavior suggests that the human presence was not a negative fact on this female's permanence in these sites.

The male ASTRO, which was released with the female LUA, with whom shared its first years of reintroduction, also was well succeeded in its routines of exploration and use of coastal environments. ASTRO had a healthy development, including from observations of courtship and intercourse behaviors with LUA when they stayed in the Mundaú-Manguaba/AL Lagoon. ASTRO has been in an area of non occurrence of the specie since the end of 1998 (LIMA, 1999). As it was demonstrated for the female $L U A$, the human interactions are due to the constant presence of people in its main areas of permanence, where although being a very conserved area, SF1 has activities related to fishing for subsistence. Other important and recorded human interaction refereed to vacations periods and intense motions from vacationers with the growing flow of motor boats, responsible for ASTRO's tramplings during four events occurred from 2001 to 2005 (BORGES et al., 2007).

Likely NINA, ALDO presented monitoring enabled by the absence of large displacements and their routines soon became known by the monitors and the local community that uses Tatuamunha River. ALDO was well succeeded in seeking food, even leaving an area more abundant (Do Patacho Beach=AR2) that the interior of the river. This region presents human activities related to fishing for subsistence and low demographic density. The environment of calm waters inside the river and freshwater are factors which can have influenced for this choice, although the beach environment is protected by reefs, but with wavy beats in shallow tide. Few were the observations of $A L D O$ and NINA's reproductive interaction in this monitoring period, 
including distinct preferential places establishment between them inside the river. ALDO always kept itself far from people, even when intensively assailed by local inhabitants, tourists and the team when the animal needed to be managed or the telemetry radio equipment repaired.

$X U X U$ also presented success in its routines of exploration and use of coastal environments, having the biggest Areas of Life among the reintroduced animals. In the first year and during a long journey to the North of its area of reintroduction, this manatee was harpooned, captured, tied to a boat and released thanks local people's intervention (Touros/RN). XUXU presented a human-interaction behavior, in any activity, in it all monitoring period, where it was common to find it near the small boats and in shore. During the period of permanence in areas of current occurrence of the marine manatee, $X U X U$ was the reintroduced animal which presented diverse records of interaction with native manatees in jointed displacements as well as reproductive behavior. Similar to ALDO, NINA was well succeeded in seeking food, even leaving from an area more abundant in aquatic plants than the interior of the small Tatuamunha River. The environment of calm waters, the freshwater and the artisan fisheries activity in the interior of the river are factors that can have influenced on this choice. NINA, unlike ALDO, presented a behavior of approximation to people when an interaction occurred.

According to BONDE et al. (2003), the adaptation of reintroduced manatees seems to be related to the age class during the release, period of captivity, procedures for recovery and pre release conditioning. The preliminary assessment of reintroductions of this species of sirenia in Brazil generated subsides for important changes in the process of recovery of animals in captivitiy (LIMA \& CASTRO, 1998) as a first Protocol for this kind of management (LIMA et al., 2007).

\section{Influence of the Areas of Reintroduction}

\section{AR1 - LUA and ASTRO}

LUA and ASTRO's Area of Reintroduction (AR1) in Paripueira had great importance on the rapid adaptation of the animals in the natural environment, so much that stayed for a long period in its surrounding (SF3). LUA and ASTRO's period of natural captivity (70 days) was the second longer period of the reintroduced manatees. The main LUA's Site of Fidelity presents the same environmental characteristics (barrier reefs, sea grass bed, mangroves, closeness to an estuary) as the place it was reintroduced. The permanence of ASTRO in the coast of Sergipe, characterized by exposed beaches and estuaries, can be a demonstration of this manatee's adaptation to several environments that the sirenia can use since find of sustainable feeding and places specific for resting. In its turn, their permanence in the interior of the Mundaú-Manguaba Lagoon can not be related to the kind of coastal environment where the AR1 was inserted in, but demonstrates many times these reintroduced manatees used the estuary areas inside their respective Areas of Life. 
The proximity with the capital city, Maceió, the accelerated urbanization and the increasing human density in the region are important factors to be analyzed so that Paripueira will continue to be the potential AR for future reintroductions.

\section{AR2 - ALDO and NINA}

ALDO and NINA's Site of Fidelity is located in the surroundings of the AR2, where Tatuamunha River ends. Due to the motions along the coastline and the proximity to the interior of the river, the influence of the localization of the Area of Reintroduction may have been important in the choice of this area of permanence as a Site of Fidelity for both. ALDO was put in the nursery of AR2 three times, had the opportunity to displace and explore the coastline but searched for the same estuarine environment protected in all those occasions.

\section{AR3 - XUXU}

This male of long term in captivity stayed for few days in the interior of the estuary where was reintroduced and soon after made one of the most extensive $(550 \mathrm{~km})$ movements among the reintroduced manatees. Even though, $X U X U$ did not use the estuary where it was reintroduced just in two years (2000 and 2003). It is important to notice that this estuary is between its two main Sites (also estuaries) and count on a frequency of occurrence of approximately $4 \%$. As it presents a highlighted seasonality of the native manatees' groups in the estuary of the Mamanguape River/PB (SILVA et al., 1992), this area of reintroduction can be considered in the scope of a Program of Reintroduction/Release, as Reinforcement/Supplementation (IUCN, 1998), by its character of adding individuals to a same existing species' population which is found in decline.

\section{ASSÚ and TICO}

These two males displaced constantly to the south and also to open sea without having stayed in the surroundings of the AR2, unlike other reintroduced manatees' movements. They also did not regularly explore other coastal areas for providing their biological needs. The possibility of keeping these animals in captivity in natural environment and for a longer period could provide the required experience so that animals which behaved like this would adapt to the coastal environment.

\section{Success Indicators of the Reintroductions}

\section{LUA, ASTRO and XUXU}


These three reintroduced manatees presented a complete adaptation to the coastal environment after their reintroduction, what was confirmed by their wide Areas of Life, which contain important environment of northeastern coast. Their biological and ecological needs were provided by their capacity on finding appropriate food, freshwater springs and protected environments for resting. The biggest LUA's success indicator was its reproduction, pregnancy and its first calf's birth in 2003, main indicator of biological success of a reintroduction (LIMA et al., 2005a). There is a high importance of this birth in a region of discontinuity of the species' current occurrence (LIMA, 1999). ASTRO's permanence (5.5 years in this study) in an area regarded as of the species' current no occurrence (Lima, 1999) makes it be the unique in that region and the manatee which is more to the south from the species' distribution. The reintroduction of other manatees in their SF1 may be important for beginning the resettlement of this area of historical occurrence (ALBUQUERQUE \& MARCOVALDI, 1982), since this animal keeps being monitored for a long term.

\section{ALDO and NINA}

These two manatees from a Area of Life restrict to a Site of Fidelity also adapted to the natural environment which satisfied their biological and ecological needs in this studying period. When observing the reproductive behavior presented by $A L D O$ since 2004 and the constant presence of the females NINA and TUCA in the restrict space also indicate that thate can stay in the interior of the estuary of Tatuamunha River for an undetermined time. The long term monitoring is necessary for the female NINA, where studies which take in account its age and reproductive period can indicate some changes in what was observed and assessed until the final of this study, in terms of Area of Life and migratory and or migratory and dispersion movements.

In terms of conservation, a strategy of a small Area of Life and fidelity to an only one Site may be dangerous if this small estuary be degraded and this animal does not have a wider knowledge of the coastal zone in a future possibility. This may be a disadvantage for them, if considering their relationship with other manatees which explored a much bigger area and use more than one Site of Fidelity, according to DEUTSCH et al. (2003). On the other hand deserving our attention, the permanent presence of these animals in Tatuamunha River has promoted the development of observation tourism of reintroduced manatees (LIMA et al., 2007), what made them important for the local economy. As being the only one SF of these reintroduced animals, in an area of the species' resettlement area, Tatuamunha River and the associated ecosystems become essentially important for conservation.

\section{ASSÚ and TICO}


These two males who had to be captured due to their weak state of health, can be considered in this study as non rehabilitated to the natural environment. ASSÚ that made an extensive and continuous movement to the south twice, did not present the habitat use and feeding observed in the other reintroduced manatees. When it was found in its second travel to the south, its was in Baia de Todos os Santos in Salvador and among big passenger ships (Ferryboat), showing a full passive behavior and no reaction to the recapture. TICO would probably die when displacing continuously to the open sea, away from a manatee's natural habitat and its very poor nutritional conditions, without being recaptured. Its recapture was only possible due to its monitoring by satellite and the team of Projeto Peixe-Boi Marinho competency and courage.

\section{CONCLUSIONS}

In Brazil, Trichechus manatus species has been protected since the 60's decade (Law 5197/67), being considered as critically endangered (IBAMA, 1997; 2001). Three federal conservation units were created for its conservation, from the subsides generated by technicians and researches of the Project within more than 20 working years. The small sample, the animal's order to be captured, the need of a daily effort for filed observations and the analysis of data resulted from these observations must be considered in this scope of this study. It is not assumed here that the behavior of spatial and temporal shown by the reintroduced manatees represents the behavior of native manatees that occur in this region. It can be assumed that those behavior are probably representative of the different kinds of behavior which the manatees raised in captivity when reintroduced can presented.

The manatees from Florida seem to learn so much with their mothers, when in their dependent stage, about displacements routes, sites of fidelity, availability of resources and threatening, where the reintroductions would be even more indicated for those sites which were near the places they were rescued (VALADE et al., 1999). Choosing the Areas of Reintroduction was based on criteria already presented in the Protocol of Reintroduction of Brazilian Manatees in Brazil (LIMA et al., 2007) instead of the stranding places of these calves. In this sense, the results of the spatial and temporal distribution of the manatees from the Areas of Reintroductions tens of kilometers away from their stranding places and without any time of learning from their mothers, can be credited to each animal's individual learning and in its turn can reflect standards for other manatees which have the same life origin and history.

The main conclusions from this study are: The manatees reintroduced presented a relative high fidelity to small areas of permanence, being those areas very environmentally similar, with shallow coastal zones protected by reefs presenting sea grass bed, estuaries and mangroves; Choosing an Area of Reintroduction (AR) from an area of discontinuity of the species' current distribution ended up a gain, once four animals established their Sites of Fidelity in the adjacent of the place for releasing. The animals reintroduced were calves and/or sub adults, but presented 
capacity of surviving and adapting to the free life in the natural environment, including the pregnancy and birth from a female which had been reintroduced four years before. Considering that this was the first study on reintroduction of manatees raised in captivity conducted in Brazil, besides the contribution for understanding the process of these animals' adaptation to free life, their movements and the habitat use, some recommendations can be offered to generate supplementary and needed knowledge on the continuity of this kind of study and for the species' conservation:

The continuity of the Program of Reintroduction of manatees stranded in the northeastern coast and raised in captivity, taking in account the Protocol of Reintroduction of the Marine Manatees in Brazil (LIMA et al.,2007) as well as the information produced by the analyzes of the monitoring data of these animals since 1994; Ecological and oceanographic studies on the spatial and temporal use by the manatees reintroduced in the Sites of Fidelity, where the daily and seasonal environmental variations must be related to the reintroduced manatees' habits and behaviors; Mapping and georeferencing the banks of marine phanerogames, the mangroves and the reefs of the studied coast, to establish the potential areas for feeding availability and use by reintroduced and native manatees; The continuity of the Area of Reintroduction in Do Patacho Beach in the north of Alagoas (AR2) and the mouth of Mamanguape River (AR3) in the northern litoral of Paraíba as important places for reintroducing and promoting studies aiming the use of Vaza Barris River in the southern coast of Sergipe and the Goiânia River, in Alagoas-Pernambuco border, as new ARs; The analysis of the data on behavior collected during these 10 years of efforts in monitoring the reintroduced animals, as well as the conduction of specific studies on the spatial use of the SF established by each animal.

\section{REFERENCES}

ALBUQUERQUE, C.; MARCOVALDI, G. M.. Ocorrência e distribuição do peixe-boi marinho no litoral brasileiro (SIRENIA, Trichechidae, Trichechus manatus, Linnaeus 1758). In: SIMPÓSIO INTERNACIONAL SOBRE UTILIZAÇÃO DE ECOSSISTEMAS COSTEIROS: PLANEJAMENTO, POLUIÇÃO E PRODUTIVIDADE. Anais. Rio Grande: Fundação Universidade do Rio Grande, 1982.

BONDE, R. K.; KEITH, L.; WARD, L.; REID, J.; PITCHFORD, T.; ROSS, M.; VALADE, J.; ADIMEY, N.. Evaluation of Post-release Success of Rehabilitated Manatees in Florida, 1973-2002. In: BIENNAL CONFERENCE ON THE BIOLOGY OF MARINE MAMMALS. 15. Anais. Greensboro, 2003.

BORGES, J. C. G.; VERGARA-PARENTE, J. E.; ALVITE, C. M. C.; MARCONDES, M. C. C.; LIMA, R. P.. Embarcações motorizadas: uma ameaça aos peixes-boi marinhos (Trichechus manatus) no Brasil. Biota Neotropica, v.7, n.3, p.199-204, 2007.

DEUTSCH, C. J.; REID, J. P.; BONDE, R. K.; EASTON, D. E.; KOCHMAN, H. I.; O'SHEA, T. J.. Seasonal Movements, Migratory Behavior and Site Fidelity of West Indian Manatees Along the Atlantic Coast Of United States. Wildlife Monographs. v.67, n.151, p1-77, 2003.

GUERRA, N. C.; MANSO, V. A.. Beachrocks (Recifes de Arenito). In: ESKINAZI-LESSA, E.; NEUMANNLEITÃO, S.; COSTA, M. F.. Oceanografia: um cenário tropical. Recife: Bagaço, 2004. 
IBAMA. Mamíferos Aquáticos do Brasil: plano de ação. Brasília: IBAMA, 1997.

IBAMA. Mamíferos Aquáticos do Brasil: plano de ação. 2 ed. Brasília: IBAMA, 2001.

LIMA, R. P.; CASTRO, D. F.. Recomendações para novas reintroduções a partir da experiência obtida com a soltura de ASTRO \& LUA (Trichechus manatus). In: REUNIÃO DE TRABALHO DE ESPECIALISTAS EM MAMÍFEROS AQUÁTICOS DA AMÉRICA DO SUL. 8. Anais. Olinda: 1998.

LIMA, R. P.. Peixe-boi marinho (Trichechus manatus): distribuição, Status de conservação e aspectos tradicionais ao longo do litoral nordeste do Brasil. Dissertação (Mestrado em Oceanografia Biológica)Universidade Federal de Pernambuco, Recife, 1997.

LIMA, R. P.. Peixe-boi marinho (Trichechus manatus): distribuição, Status de conservação e aspectos tradicionais ao longo do litoral nordeste do Brasil. Brasília: IBAMA, 1999.

LIMA, R. P.; CASTRO, D. F.; VERGARA, J. E.; ALVITE, C. M. C.. Avaliação do Sistema de Monitoramento de peixes-bois marinho (Trichechus manatus) reintroduzidos no litoral nordeste do Brasil. In: REUNIÓN DE TRABALJO DE ESPECIALISTAS EN MAMIFEROS ACUATICOS DEL AMERICA DEL SUR, 9. Anais.

Buenos Aires, 2000.

LIMA, R. P.; ALVITE, C. M. C; VERGARA-PARENTE, J. E.. Protocolo de Reintrodução de Peixes-bois marinhos no Brasil. São Luís: IBAMA, 2007.

LIMA, R. P.; ALVITE, C. M. C; REID, J.; BOMBASSARO JUNIOR, A.. Distribuição espacial e temporal de peixes-bois (Trichechus manatus) reintroduzidos no litoral nordeste do Brasil. Natural Resources, v.2, p.63, 2012.

PRIMACK, R. B.; RODRIGUES, E.. Biologia da Conservação. Londrina: Planta, 2001.

SILVA, K. G.; PALUDO, D.; OLIVEIRA, E. M. A.; LIMA, R. P.; SOAVINSKI, R. J.. Distribuição e ocorrência do peixe-boi marinho (Trichechus manatus) no estuário do rio Mamanguape, Paraíba-Brasil. Periódico Peixe-Boi/IBAMA-FMM, João Pessoa, v.1, n.1, p.6-18, 1992.

VALADE, J. A.; BOSSART, G.; FROHLICH, K.; LEFEBVRE, L.; MIGNUCCI-GIANNONI, A.; MURPHY, D.; PEARSON, J.; POWELL, J.. The manatee rescue, rehabilitation, and release program: an overview. In: THIRTEEN BIENNAL CONFERENCE ON THE BIOLOGY OF MARINE MAMMALS. Anais. Wailea 1999. 
Assessment of the first decade (1994-2004) of west indian manatee' reintroduction (trichechus manatus) program in the... 
